\title{
Analisis Kualitas Air dan Kepadatan Moluska pada Kawasan Ekosistem Mangrove, Nusa Lembongan
}

\author{
Made Ayu Pratiwi ${ }^{a} *$, Ni Made Ernawati ${ }^{a}$ \\ ${ }^{a}$ Program Studi Manajemen Sumberdaya Perairan, Fakultas Kelautan dan Perikanan, Universitas Udayana, Kampus Bukit Jimbaran, Bali 80361, \\ Indonesia \\ * Penulis koresponden. Tel.: +62-878-5743-5683 \\ Alamate-mail: mayupratiwi@gmail.com
}

Diterima (received) 22 Juni 2016; disetujui (accepted) 19 November 2016; tersedia secara online (available online) 20 November 2016

\begin{abstract}
Mangrove is one of the coastal ecosystem is able to grow in fluctuating water conditions. Mangrove areas are found on the Nusa Lembongan island, Bali, is a mangrove ecosystem that have the unique characteristics of water area. The mangrove area is located on one of the small islands in Bali that have no source of freshwater input and there is the entrance of water into the mangrove forest. The uniqueness of waters in mangrove ecosystem will affect the type and density of fauna associated, particularly mollusca. Mollusca are one of the animals that live and thrive in the mangrove ecosystem. Therefore, it is necessary to study which aimed to provide a description of the water quality and mollusca on mangrove ecosystem in Nusa Lembongan. This research was conducted in June 2015 on a six station observation. Measurement of water quality conducted on four water parameters such as temperature, $\mathrm{DO}, \mathrm{pH}$, and salinity. Observation on the type and density of mollusca done using transects squared (1 x 1 meter). The range of values obtained water quality parameters, such as; 1) salinity (32.00-34.33 ppm), 2) pH (7.06-7.96), 3) temperature (27.27-30.13 Celsius), and 4) DO (2.60-6.90 mg/l). Water quality parameter values obtained are still in the range of water quality standard and suitable place to live and grow for marine biota life. Dissolved oxygen (DO) value was still below the threshold quality standard. There six families of mollusca found in six observation station, such as Neritidae, Littorinidae, Columbellidae, Olividae, Carditidae, Muricidae, Potamidae, Certthiidae. The highest density was in Family Potamidae $\left(1.83 \mathrm{ind} / \mathrm{m}^{2}\right)$, so the Family Potamidae is able to adapt and have a wide area deployment.
\end{abstract}

Keywords: Nusa Lembongan Island; mangrove ecosystem;molusca; water quality

\begin{abstract}
Abstrak
Mangrove merupakan salah satu ekosistem pesisir yang mampu tumbuh dan berkembang dengan baik pada kondisi perairan yang berfluktuasi. Kawasan mangrove yang terdapat pada Pulau Nusa Lembongan, Bali merupakan kawasan mangrove yang memiliki karakteristik perairan yang sangat unik. Kawasan mangrove ini berada pada salah satu Pulau Kecil di Bali yang tidak memiliki sumber masukan air tawar dan terdapat jalur masuk air ke dalam hutan mangrove. Keunikan perairan pada kawasan ekosistem mangrove tersebut akan mempengaruhi jenis dan kepadatan fauna yang berasosiasi didalamnya, khususnya moluska. Moluska merupakan salah satu hewan yang hidup dan berkembang baik pada ekosistem mangrove. Oleh karena itu, perlu dilakukan penelitian yang bertujuan untuk memberikan gambaran kondisi kualitas perairan dan moluska pada ekosistem mangrove di Nusa Lembongan. Penelitian ini dilakukan pada Bulan Juni 2015 pada enam titik pengamatan. Pengukuran kualitas perairan dilakukan terhadap empat parameter perairan yaitu suhu, DO, pH, dan salinitas. Pengamatan terhadap jenis dan kepadatan moluska dilakukan dengan menggunakan transek kuadrat (1 x 1 meter). Kisaran nilai parameter kualitas perairan yang didapat yaitu; 1) salinitas (32.00-34.33 ppm), 2) pH (7.06-7.96), 3) suhu (27.27-30.13 Celcius), dan 4) DO (2.60-6.90 mg/l). Nilai parameter kualitas air yang didapatkan masih berada pada kisaran baku mutu dan sesuai untuk tempat hidup dan berkembang bagi biota perairan. Terdapat satu parameter kualitas perairan yang nilainya masih di bawah ambang batas baku mutu yaitu parameter oksigen terlarut (DO). Terdapat enam famili moluska yang ditemukan pada enam titik pengamatan yaitu Neritidae, Littorinidae, Columbellidae, Olividae, Carditidae, Muricidae, Potamidae, Certthiidae. Kepadatan tertinggi yaitu pada famili Potamidae $\left(1.83 \mathrm{ind} / \mathrm{m}^{2}\right)$, sehingga Famili Potamidae merupakan famili yang mampu beradaptasi dan memiliki wilayah penyebaran yang luas.
\end{abstract}

Kata Kunci: ekosistem mangrove; kualitas perairan; moluska; Nusa Lembongan

\section{Pendahuluan}

Mangrove merupakan tumbuhan daratan berupa semaksemak belukar dan pohon-pohon yang bertahan hidup dengan beradaptasi dengan cara yang luar biasa pada kondisi asin (Parida and Jha, 2010). Ekosistem mangrove terdapat pada daerah yang terlindung dari gelombang besar dan arus pasang surut kuat, dimana air pada ekosistem ini bersalinitas payau hingga asin (Alongi, 2008). Ekosistem mangrove berada pada daerah yang kondisi perairannya dipengaruhi pasang surut air laut, sehingga kondisi perairan pada ekosistem mangrove sangat berfluktuasi (Kristensen et al., 2008; Feller et al., 2010). 
Ekosistem mangrove juga merupakan habitat yang sangat unik, karena selain mampu hidup dan berkembang biak pada kondisi perairan yang berfluktuasi pasang surut. Mangrove juga memiliki peranan penting yaitu sebagai daerah asuhan, pemijahan, dan pembesaran juvenile ikan. Mangrove di Nusa Lembongan sendiri memiliki keunikan lainnya yaitu terdapat jalur air masuk ke dalam hutan mangrove sehingga menyebabkan keunikan dan fluktuasi kondisi kualitas perairan ekosistem mangrove.

Keunikan dan kondisi kualitas perairan kawasan mangrove di Nusa Lembongan akan mempengaruhi kondisi fauna yang berasosisasi didalamnya. Salah satu jenis fauna yang hidup pada ekosistem mangrove yaitu Filum Moluska. Moluska merupakan hewan lunak yang mempunyai cangkang dan banyak ditemukan di ekosistem mangrove yang hidup di permukaan substrat maupun di dalam substrat dan menempel pada pohon mangrove (Hartoni dan Agussalim 2013). Moluska juga dapat digunakan sebagai biondikator dari limbah domestik yang terdapat pada kawasan hutan Mangrove (Cannicci et al., 2009). Kelas gastropoda dan bivalvia merupakan jenis moluska yang paling banyak ditemukan hidup pada ekosistem mangrove. Berdasarkan hasil penelitian Faiqoh dkk. (2016) di kawasan hutan Mangrove Pulau Penyu Tanjung Benoa-Bali, terdeteksi bahwa gastropoda dan bivalvia adalah dua jenis makrozoobenthos yang paling banyak kelimpahannya.

Berdasarkan tinjauan di atas, maka perlu dilakukan penelitian mengenai analisis kualitas air dan kepadatan moluska pada kawasan ekosistem mangrove, Nusa Lembongan. Penelitian ini bertujuan untuk memberikan gambaran kondisi kualitas perairan dan moluska pada kawasan ekosistem mangrove, Nusa Lembongan.

\section{Metode Penelitian}

\subsection{Waktu dan Lokasi Penelitian}

Penelitian ini dilakukan di kawasan ekosistem mangrove Nusa Lembongan, Bali. Pengambilan contoh dilaksanakan pada tanggal 13 Juni hingga 14 Juni 2015. Pengamatan terhadap kualitas perairan dan moluska kawasan mangrove dimulai pada pukul 09.37 hingga 18.00 WITA.

\subsection{Titik Pengambilan Sampel}

Pengamatan ekosistem mangrove dilakukan pada enam titik pengamatan yang mewakili kondisi mangrove secara keseluruhan. Titik pengamatan 1 dan 2 terletak pada kawasan mangrove yang dilalui oleh jalur air dan dijadikan sebagai tempat wisata. Titik pengamatan 3 dan 4 merupakan titik pengamatan yang paling dekat dengan laut dan berasosiasi dengan ekosistem lamun. Titik pengamatan 5 dan 6 berada pada kawasan mangrove yang lebih dekat ke daratan. Titik pengamatan tersebut dapat dilihat pada Gambar 1.

\subsection{Metode Pengambilan Sampel}

Pengamatan moluska pada ekosistem mangrove dilakukan dengan metode transek kuadrat. Luasan transek yang dipakai yaitu 1 x $1 \mathrm{~m}^{2}$. Pengambilan data kualitas air meliputi suhu, $\mathrm{pH}$, salinitas, dan DO dilakukan didalam transek pengamatan moluska. Diagram alir metode pengamatan kualitas perairan kawasan mangrove di Pulau Nusa Lembongan disajikan pada Gambar 2.

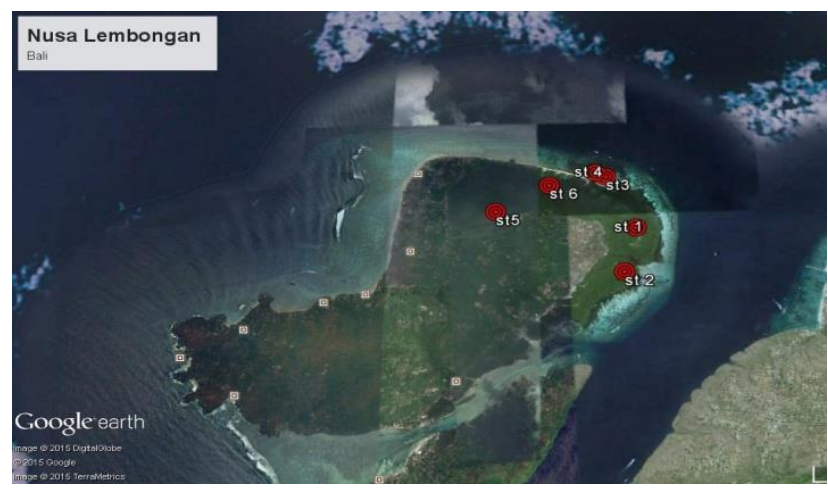

Gambar 1. Pulau Nusa Lembongan dan stasiun pengambilan sampel di kawasan hutan Mangrove

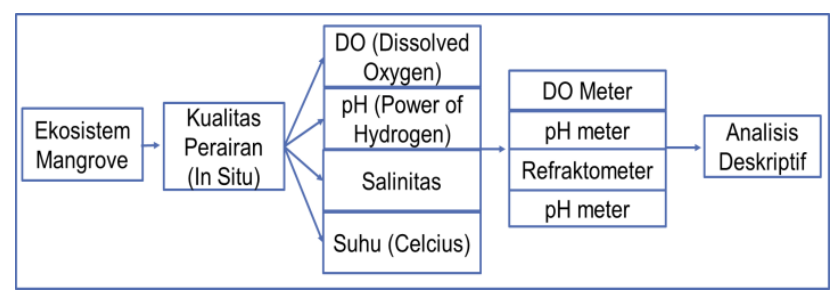

Gambar 2. Diagram alir metode pengamatan kualitas perairan kawasan mangrove

\subsection{Analisis Data Moluska}

Kepadatan moluska adalah jumlah individu moluska per satuan luas atau volume area yang di hitung menggunakan persamaan (Brower et al., 1998)

$$
D i=\frac{n i}{A}
$$

Keterangan :

$$
\begin{array}{ll}
\mathrm{R} & =\text { Kepadatan moluska jenis ke-i (spesies) } \\
\mathrm{ni} & =\text { Jumlah individu setiap jenis }(\mathrm{ind}) \\
\mathrm{A} & \text { = Luas area plot pengamatan }\left(\mathrm{m}^{2}\right)
\end{array}
$$

\section{Hasil dan Pembahasan}

\subsection{Hasil}

\subsubsection{Kualitas Perairan}

Kualitas perairan merupakan salah satu variable penting yang mempengaruhi kondisi pada ekosistem mangrove. Pengamatan telah dilakukan terhadap enam titik pada ekosistem mangrove dan didapatkan nilai Salinitas, $\mathrm{pH}$, Suhu dan DO yang berfluktuasi.

Kisaran nilai salinitas berkisar antara 32.00-34.33 ppm. Nilai Salinitas tertinggi yaitu pada stasiun 4 sebesar 34.33 ppm, sedangkan nilai salinitas terendah yaitu pada stasiun 3 yaitu sebesar 31.33 ppm (Gambar 3). Perbedaan 
nilai salinitas ini dapat disebabkan oleh perbedaan lokasi stasiun pengamatan.

Tabel 1

Nilai parameter Kualitas Perairan di Kawasan Ekosistem Mangrove, Nusa Lembongan

\begin{tabular}{ccccccc}
\hline \multirow{2}{*}{ St. } & \multicolumn{2}{c}{ Koordinat } & $\begin{array}{c}\text { Salin- } \\
\text { itas }\end{array}$ & pH & Suhu & DO \\
\cline { 2 - 6 } & $\mathrm{S}$ & $\mathrm{E}$ & & & \\
\hline 1 & $08^{\circ} 40^{\prime} 055^{\prime \prime}$ & $115^{\circ} 28^{\prime} 101^{\prime \prime}$ & 33.00 & 7.71 & 27.27 & 6.90 \\
2 & $08^{\circ} 40^{\prime} 180^{\prime \prime}$ & $115^{\circ} 28^{\prime} 082^{\prime \prime}$ & 33.00 & 7.06 & 27.40 & 3.50 \\
3 & $08^{\circ} 39^{\prime} 951^{\prime \prime}$ & $115^{\circ} 28^{\prime} 011^{\prime \prime}$ & 31.33 & 7.84 & 30.13 & 5.80 \\
4 & $08^{\circ} 39^{\prime} 980^{\prime \prime}$ & $115^{\circ} 28^{\prime} 076^{\prime \prime}$ & 34.33 & 7.96 & 30.00 & 4.63 \\
5 & $08^{\circ} 39^{\prime} 972^{\prime \prime}$ & $115^{\circ} 27^{\prime} 226^{\prime \prime}$ & 32.00 & 7.58 & 28.60 & 2.90 \\
6 & $08^{\circ} 40^{\prime} 251^{\prime \prime}$ & $115^{\circ} 27^{\prime} 537^{\prime \prime}$ & 32.33 & 7.23 & 28.57 & 2.60 \\
\hline
\end{tabular}

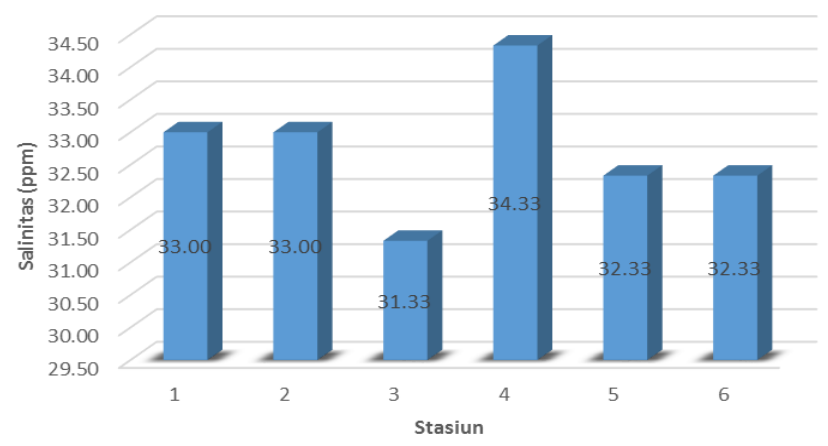

Gambar 3. Grafik Perbandingan Nilai Salinitas di 6 Stasiun Pengamatan

Kisaran pH yang didapatkan 7.06-7.96, dimana nilai $\mathrm{pH}$ tertinggi terdapat pada stasiun 4 (7.96) dan $\mathrm{pH}$ terendah pada stasiun 2 (7.06) (Gambar 4). Effendie (2000) menyatakan bahwa sebagian besar biota aquatik menyukai pH sekitar 7-8.5. Hal ini berarti bahwa perairan sekitar mangrove di Nusa Lembongan masih dalam kondisi $\mathrm{pH}$ yang stabil dan baik untuk biota aquatik.

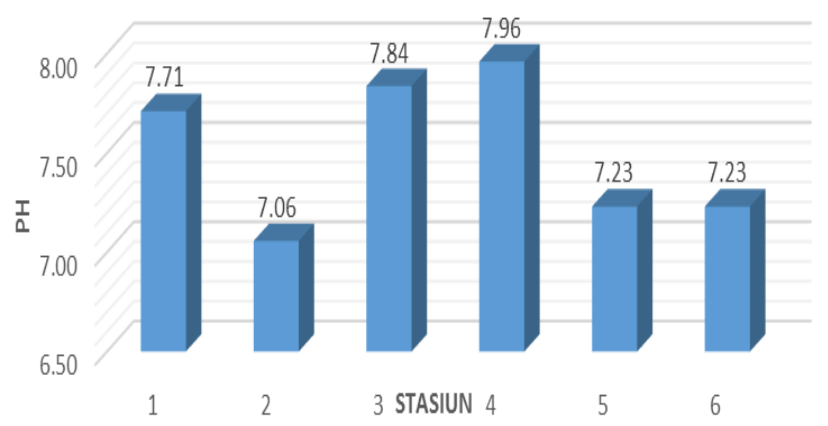

Gambar 4. Grafik Perbandingan Nilai $\mathrm{pH}$ di 6 Stasiun Pengamatan

Berdasarkan Gambar 5. didapatkan bahwa kisaran nilai suhu yang didapatkan yaitu sebesar 27.27-30.13 Celcius. Kisaran suhu tersebu termasuk kisaran suhu yang dapat dijadikan tempat biota untuk hidup dan berkembang.

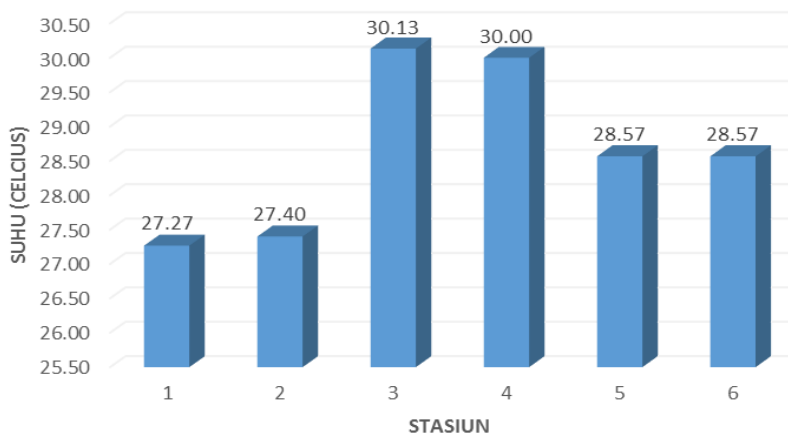

Gambar 5. Grafik Perbandingan Nilai Suhu di 6 Stasiun Pengamatan

Nilai DO yang didapatkan berkisar antara 2.60-6.90 $\mathrm{mg} / \mathrm{l}$ (Gambar 6). Nilai DO tertinggi yaitu pada stasiun 1 (6.90 mg/l), sedangkan nilai DO terendah yaitu pada stasiun 5 dan $6(2.60 \mathrm{mg} / \mathrm{l})$. Tingginya nilai DO pada stasiun 1 mungkin disebabkan karena suhu pada stasiun 1 cukup rendah. Daya larut oksigen dapat berkurang akibat naikknya suhu air dan meningkatnya salinitas (Wijayanti 2007).
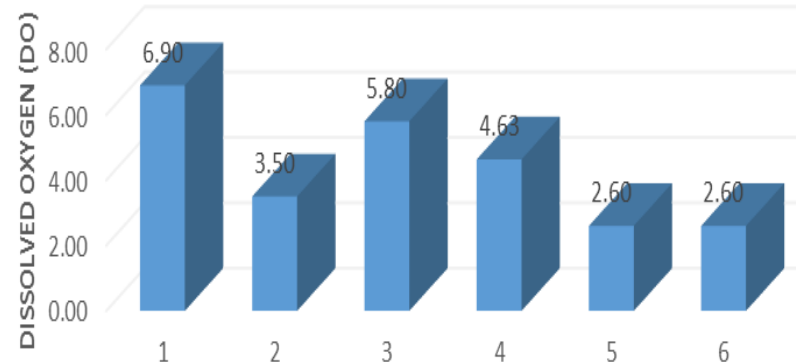

STASIUN

Gambar 6. Grafik Perbandingan Nilai DO di 6 Stasiun Pengamatan

\subsubsection{Kondisi Moluska}

Moluska merupakan salah satu jenis fauna yang berasosiasi pada ekosistem mangrove. Identifikasi jenis moluska pada ekosistem mangrove sangat penting dilakukan. Menurut Cintra (2013) faktor biologi misalnya epifauna turut mempengaruhi dalam suksesi vegetasi mangrove terutama akibat dari kebiasaan makan organisme tersebut. Jenis famili moluska yang ditemukan pada enam titik pengamatan yaitu Neritidae, Littorinidae, Columbellidae, Olividae, Carditidae, Muricidae, Potamidae, Certthiidae (Tabel 2). Dari delapan jenis moluska yang ditemukan, famili Neritidae dan Potamidae merupakan famili yang paling sering ditemukan.

Kepadatan merupakan banyaknya individu dalam suatu luasan area tertentu. Kepadatan moluska tertinggi pada Famili Potamidae sebesar 1.83 ind $/ \mathrm{m}^{2}$, sedangkan kepadatan terendah pada Famili Muricidae sebesar 0.17 ind $/ \mathrm{m}^{2}$ (Gambar 7). Perbedaan kepadatan moluska tersebut dapat disebabkan oleh perbedaan kerapatan mangrove, perbedaan kualitas perairan dan tipe substrat mangrove. 
Tabel 2

Famili Moluska yang ditemukan pada enam titik pengamatan

\begin{tabular}{lllllll}
\hline \multicolumn{1}{c}{ Famili Moluska } & 1 & 2 & 3 & 4 & 5 & 6 \\
\hline Neritidae & & $\sqrt{ }$ & & & $\sqrt{ }$ & $\sqrt{ }$ \\
Littorinidae & & & $\sqrt{ }$ & $\sqrt{ }$ & & \\
Columbellidae & & & & $\sqrt{ }$ & & \\
Olividae & & & & & & $\sqrt{ }$ \\
Carditidae & $\sqrt{ }$ & & & & \\
Muricidae & & & & & $\sqrt{ }$ & \\
Potamidae & & & $\sqrt{ }$ & $\sqrt{ }$ & $\sqrt{ }$ & \\
Cerithiidae & & & $\sqrt{ }$ & & \\
\hline
\end{tabular}

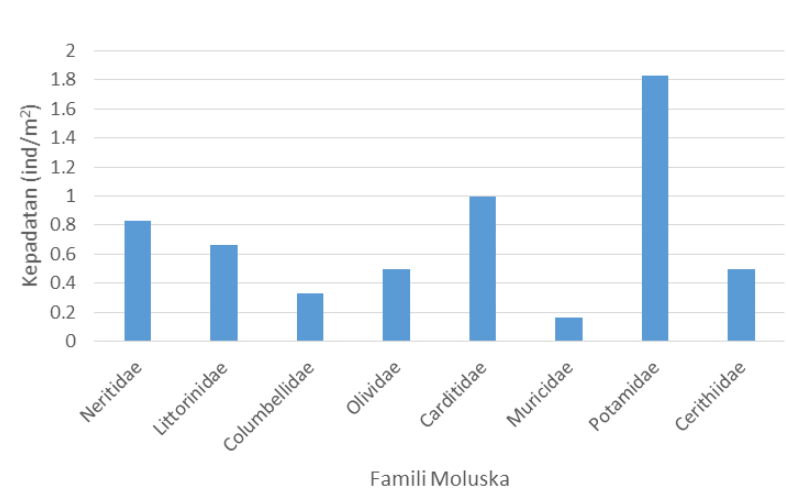

Gambar 7. Grafik kepadatan moluska (ind $/ \mathrm{m}^{2}$ ) pada enam titik pengamatan

\subsection{Pembahasan}

3.2.1 Kondisi Lingkungan Perairan di Kawasan Mangrove Nusa Lembongan

Hasil pengukuran karakteristik fisika dan kimia perairan kawasan mangrove di Nusa Lembongan, menunjukkan bahwa nilai-nilai yang di peroleh dari hasil penelitian masih tergolong dalam kategori normal. Kisaran nilai suhu 27.27 - 30.13 Celcius masih berada pada kisaran baku mutu untuk biota laut pada ekosistem mangrove (2832 celcius) (Kepmen LH 2004). Hal ini berarti kisaran suhu di kawasan mangrove Nusa Lembongan masih berada pada kisaran hidup untuk biota laut. Perbedaan nilai suhu pada setiap titik pengamatan disebabkan oleh perbedaan waktu pengambilan data (Tabel 3) dan kerapatan mangrove. Nilai Suhu yang rendah terdapat pada stasiun pengamatan 1 dan 2 . Hal ini disebabkan oleh kerapatan mangrove pada stasiun 1 dan 2 yang cukup padat mampu menghalangi intensitas cahaya matahari menuju perairan meskipun pengambilan data dilakukan pada siang hari. Nilai suhu yang tinggi pada stasiun 3 dan 4 disebabkan letak stasiun tersebut yang berada paling dekat dengan laut dan berasosiasi dengan ekosistem lamun. Hal tersebut juga disebabkan oleh kondisi kepadatan mangrove yang jarang pada stasiun 3 dan 4 .

Kelimpahan garam merupakan kerakteristik perairan yang paling penting bagi hutan mangrove dan sebagian besar hutan mengrove menyerap beberapa sodium dan ion klorida (Lu et al., 2013). Menurut Lewis et al. (2011), mangrove biasanya tumbuh subur di daerah estuari dengan tingkat salinitas antara 10-30 \%o. Rata-rata salinitas yang didapatkan pada keenam titik pengamatan yaitu 32.78 ppm. Rata-rata nilai salinitas tersebut lebih besar dari kisaran salinitas untuk kesuburan mangrove (Ezawa and Tada, 2009; Munns and Tester, 2008; Wang et al., 2010), namun masih pada kisaran salinitas dimana mangrove dapat tumbuh berkembang (Flowers and Colmer, 2015). Secara spesifik, tanaman mangrove dapat tumbuh pada substrat yang sangat saline dan bahkan tumbuh lebih baik pada air dengan kadar garam tinggi (Yan and Guizhu, 2007; Lambs et al., 2008; Liang et al., 2008).

Tabel 3

Waktu Pengambilan Data

\begin{tabular}{clc}
\hline \multirow{2}{*}{ Stasiun } & \multicolumn{1}{c}{ Tanggal } & Waktu \\
\hline 1 & Sabtu, 13 Juni 2015 & $11.00-11.50$ \\
2 & Sabtu, 13 Juni 2015 & $12.12-13.00$ \\
3 & Sabtu, 13 Juni 2015 & $14.50-15.45$ \\
4 & Sabtu, 13 Juni 2015 & $17.18-18.00$ \\
5 & Minggu, 14 Juni 2015 & $09.37-10.40$ \\
6 & Minggu, 14 Juni 2015 & $11.04-12.00$ \\
\hline
\end{tabular}

Rata-rata nilai $\mathrm{pH}$ yang didapatkan pada keenam titik pengamatan yaitu 7.56. Rata-rata nilai $\mathrm{pH}$ tersebut masih berada pada kisaran baku mutu perairan untuk biota mangrove (7-8.5) (Kepmen LH 2004). Hal ini berarti bahwa nilai $\mathrm{pH}$ berada pada kisaran pertumbuhan yang baik untuk mangrove.

Nilai DO yang didapatkan berkisar anatara 2.60-6.90 $\mathrm{mg} / \mathrm{l}$ dengan rata-rata nilai DO sebesar $4.39 \mathrm{mg} / \mathrm{l}$. Terdapat empat titik pengamatan dengan nilai DO dibawah ambang baku mutu Kepmen LH, 2004 (> 5 $\mathrm{mg} / \mathrm{l}$ ), yaitu pada titik $2,4,5$, dan 6 . Hanya pada titik 1 dan 3 yang memiliki kisaran DO yang baik untuk pertumbuhan mangrove yaitu $>5 \mathrm{mg} / \mathrm{l}$. Rendahnya nilai DO untuk titik 5 dan 6 dapat disebabkan karena letak titik pengamatan yang lebih kearah darat, sehingga menyebabkan fluktuasi air cenderung lambat. Pengamatan yang dilakukan di titik 5 dan 6 yaitu pada kondisi surut sehingga tidak ada pergerakan massa air. Hal tersebut memungkinkan difusi $\mathrm{O}_{2}$ ke perairan menjadi lambat.

Rendahnya nilai DO pada keempat titik pengamatan diatas juga dapat disebabkan oleh nilai suhu perairan yang tinggi, yaitu mencapai 34.33 celcius pada stasiun 4 . Hal ini disebabkan oleh dengan semakin tingginya suhu perairan maka akan berbanding terbalik dengan kadar oksigen terlaur (DO) pada perairan. Malik (2013) menyatakan bahwa kelarutan oksigen di dalam air merupakan fungsi dari suhu dan salinitas dan kelarutan oksigen semakin rendah dengan meningkatnya suhu dan salinitas. 
3.2.2 Kondisi Moluska di Kawasan Mangrove Nusa Lembongan

Moluska merupakan salah satu organisme yang berasosiasi dengan ekosistem mangrove yang hidupnya menempel pada permukaan susbtrat. Pada keenam titik pengamatan diperoleh kepadatan rata-rata famili moluska sebesar $0.73 \mathrm{ind} / \mathrm{m}^{2}$. Jumlah jenis famili moluska terbanyak yang ditemukan pada keenam titik pengamatan yaitu famili Potamidae sebanyak 11 individu, sedangkan jumlah jenis terendah terdapat pada famili Muricidae sebanyak 1 individu. Famili Potamidae juga memiliki kepadatan tertinggi, sehingga dapat dikatakan bahwa Famili Potamidae mampu beradaptasi dan cocok pada kondisi lingkungan ekosistem mangrove di Nusa Lembongan. Odum (1998) menyatakan bahwa suatu spesies yang mempunyai kepadatan tertinggi menunjukan bahwa organisme ini memiliki kemampuan menempati ruang yang lebih luas sehingga kesempatan untuk berkembang lebih banyak. Famili Potamidae juga memiliki wilayah penyebaran paling tinggi yaitu ditemukan pada 3 titik pengamatan (3, 4, dan 5). Hal ini berarti bahwa famili Potamidae memiliki adaptasi yang tinggi terhadap kondisi kualitas perairan di Nusa Lembongan.

Perbandingan dilakukan terhadap kawasan ekosistem mangrove yang terdapat di Desa Kulu, Kabupaten Minahasa Utara. Pada kawasan ekosistem mangrove tersebut diperoleh 11 jenis moluska dari 8 famili dengan spesies Littoraria scabra merupakan spesies yang memiliki kepadatan tertinggi (Rau et al. 2013). Spesies Littoraria scabra yaitu merupakan Famili Littorinidae. Perbedaan kepadatan tertinggi pada famili tersebut dapat disebabkan oleh perbedaan tipologi dan jenis mangrove di kedua kawasan tersebut.

\section{Simpulan}

Kisaran nilai kondisi perairan di kawasan mangrove Nusa Lembongan telah mampu untuk mendukung pertumbuhan dan perkembangan biota perairan pada ekosistem mangrove. Hanya terdapat satu parameter kualitas perairan yang nilainya masih di bawah ambang batas baku mutu yaitu pada nilai oksigen terlarut (DO). Terdapat enam famili moluska yang ditemukan pada enam titik pengamatan yaitu Neritidae, Littorinidae, Columbellidae, Olividae, Carditidae, Muricidae, Potamidae, Cerithiidae. Kerapatan moluska tertinggi yaitu pada famili Potamidae (1.83 ind $\left./ \mathrm{m}^{2}\right)$ dan juga memiliki wilayah penyebaran tertinggi yaitu pada tiga titik pengamatan.

\section{Ucapan terimakasih}

Kepada Lembaga Penelitian dan Pengabdian Kepada Masyarakat (LPPM) Universitas Udayana, Dekan Fakultas Kelautan dan Perikanan, Fakultas Kelautan dan Perikanan Universitas Udayana, Masyarakat Desa Jungut Batu Nusa Lembongan.

\section{Daftar Pustaka}

Alongi, D. M. (2008). Mangrove forests: resilience, protection from tsunamis, and responses to global climate change. Estuarine, Coastal and Shelf Science, 76(1), 1-13.

Brower, J. E., Zar, J. H., \& von Ende, C. (1998). Field and Laboratory Methods for General Ecology. (3rd ed.). Dubuque, Iowa: Wm. C. Brown Publishers.

Cannicci, S., Bartolini, F., Dahdouh-Guebas, F., Fratini, S., Litulo, C., Macia, A., Mrabu, E. J., Penha-Lopes, G., \& Paula, J. (2009). Effects of urban wastewater on crab and mollusc assemblages in equatorial and subtropical mangroves of East Africa. Estuarine, Coastal and Shelf Science, 84(3), 305-317.

Effendie H. (2000). Telaah Kualitas Air. Bogor-Indonesia: Manajemen Sumberdaya Perairan, Institut Pertanian Bogor.

Ezawa, S., \& Tada, Y. (2009). Identification of salt tolerance genes from the mangrove plant Bruguiera gymnorhiza using Agrobacterium functional screening. Plant Science, 176(2), 272-278.

Faiqoh, E., Hayati, H., \& Yudiastuti, K. (2016). Studi Komunitas Makrozoobenthos di Kawasan Hutan Mangrove Pulau Penyu, Tanjung Benoa, Bali. Journal of Marine and Aquatic Sciences, 2(1), 23-28.

Feller, I. C., Lovelock, C. E., Berger, U., McKee, K. L., Joye, S. B., \& Ball, M. C. (2010). Biocomplexity in mangrove ecosystems. Annual Review of Marine Science, 2, 395-417.

Flowers, T. J., \& Colmer, T. D. (2015). Plant salt tolerance: adaptations in halophytes. Annals of botany, 115(3), 327-331.

Gunarto. (2004). Konservasi mangrove sebagai pendukung sumber hayati perikanan pantai. Jurnal penelitian dan pengembangan pertanian, $\mathbf{2 3}(1), 15-21$.

Hartoni, \& Agussalim, A. (2013). Komposisi dan Kelimpahan Moluska (Gastropoda dan Bivalvia) di Ekosistem Mangrove Muara Sungai Musi Kabupaten Banyuasin Provinsi Sumatera Selatan. Maspari Journal, 5(1), 6-15.

Kristensen, E., Bouillon, S., Dittmar, T., \& Marchand, C. (2008). Organic carbon dynamics in mangrove ecosystems: a review. Aquatic Botany, 89(2), 201-219.

Lambs, L., Muller, E., \& Fromard, F. (2008). Mangrove trees growing in a very saline condition but not using seawater. Rapid Communications in Mass Spectrometry, 22(18), 28352843.

Lewis, M., Pryor, R., \& Wilking, L. (2011). Fate and effects of anthropogenic chemicals in mangrove ecosystems: a review. Environmental pollution, 159(10), 2328-2346.

Liang, S., Zhou, R., Dong, S., \& Shi, S. (2008). Adaptation to salinity in mangroves: Implication on the evolution of salttolerance. Chinese Science Bulletin, 53(11), 1708-1715.

Lu, Y., Li, N., Sun, J., Hou, P., Jing, X., Zhu, H., Deng, S., Han, Y., Huang, X., Ma, X., Zhao, N., Zhang, Y., Shen, X., \& Zhao, N. (2013). Exogenous hydrogen peroxide, nitric oxide and calcium mediate root ion fluxes in two non-secretor mangrove species subjected to $\mathrm{NaCl}$ stress. Tree physiology, 33(1), 81-95.

Malik, A. (2013). Analisis kualitas air pada kerapatan mangrove yang berbeda di Kabupaten Barru. Octopus, 2(2), 197-201.

Munns, R., \& Tester, M. (2008). Mechanisms of salinity tolerance. Annual Review of Plant Biology, 59, 651-681.

Odum, E.P. 1998. Dasar-dasar ekologi. Terjemahan T. Samingan dan B. Srigdanono. Yogyakarta-Indonesia: Gajah Mada Press.

Parida, A. K., \& Jha, B. (2010). Salt tolerance mechanisms in mangroves: a review. Trees, 24(2), 199-217. 
Rau, A. R., Kusen, J. D., \& Paruntu, C. P. (2013). Struktur Komunitas Moluska Di Vegetasi Mangrove Desa Kulu, Kecamatan Wori, Kabupaten Minahasa Utara. Jurnal Pesisir dan Laut Tropis, 2(1), 44-50.

Yan, L., \& Guizhu, C. (2007). Physiological adaptability of three mangrove species to salt stress. Acta Ecologica Sinica, 27(6), 2208-2214.

Wang, L., Mu, M., Li, X., Lin, P., \& Wang, W. (2011). Differentiation between true mangroves and mangrove associates based on leaf traits and salt contents. Journal of Plant Ecology, 4(4), 292-301.

Wijayanti, H. (2007). Kajian Kualitas Perairan di Pantai Kota Bandar Lampung Berdasarkan Komunitas Hewan Makrobenthos. Tesis. Semarang-Indonesia: Program Magister Manajemen Sumberdaya Pantai Universitas Diponegoro.

(C) 2016 by the authors; licensee Udayana University, Indonesia. This article is an open access article distributed under the terms and conditions of the Creative Commons Attribution license (http://creativecommons.org/licenses/by/3.0/). 